\title{
PEMBUATAN NOWOVEN INSULATOR ME MANFAATKAN BAHAN LIMBAH BULU AYAM DAN KASA POLIPROPILEN
}

\author{
MAKING OF NOWOVEN INSULATOR USING CHICKEN FEATHER WASTE \\ AND POLYPOPYLNE SCREEN
}

\author{
Asril Senoaji Soekoco, Muhammad Ichwan, Agus Hananto, Dody Mustafa \\ Teknik Tekstil, Politeknik STTT Bandung, Indonesia \\ E-mail: asril-s@kemenperin.go.id
}

\begin{abstract}
ABSTRAK
Pada tahun 2017 konsumsi daging ayam konsumen Indonesia diprediksi mencapai 4,69 kg/kapita sehingga membutuhkan 1,24 juta ton daging ayam, dengan kandungan bulu ayam $5 \%$ dari bobot ayam maka dihasilkan sebanyak 62.000 ton/tahun limbah bulu ayam. Saat ini di Indonesia limbah bulu ayam baru dimanfaatkan untuk bahan baku pakan ternak kualitas rendah, sebagai pembersih seperti kemoceng, untuk pengisi bantal dan boneka. Potensi limbah bulu ayam untuk bahan baku tekstil insulator masih belum banyak diteliti. Bulu ayam memiliki sifat ringan, kuat, berpori, dan sedikit hidrofob sehingga sangat potensial digunakan sebagai material insulator tekstil. Pada penelitian ini limbah bulu ayam dipilah dan dibersihkan dengan proses kimia kemudian diproses menjadi kain nowoven bersama jaring polipropilen dengan metode themal bonded. Percobaan dilakukan dengan memvariasikan perbandingan arah orientasi bulu ayam untuk menghasilkan material insulator yang optimal yang ditinjau dari kekuatan tarik dan mulur kain, sifat termal dan area density. Hasil pengujian area density (gramasi) diketahui bahwa gramasi kain nowoven insulator yang berbahan utama limbah bulu ayam memiliki nilai lebih dari 14 kali lipat dari gramasi material insulator komersial. Hasil pengujian uji tarik menunjukan kain nowoven berbahan utama limbah bulu ayam dengan arah orientasi unidirectional memiliki kekuatan tarik 6 kali lebih tinggi dibandingkan dengan kekuatan tarik material insulator komersial
\end{abstract}

Kata kunci: bulu ayam, thermal bonded, nowoven, insulator

\begin{abstract}
In 2017 consumption of Indonesian chicken meat is predicted $4.69 \mathrm{~kg} /$ capita, it needs 1.24 million tons of chicken meat for whole country. The percentage of chicken feather content is $5 \%$ of chicken weight, it means there will be 62.000 tons / year of chicken feather waste in 2017. Currently in Indonesia, the chicken feather waste is commonly used for low-quality animal feed raw materials, cleansers such as duster, filler pillows and dolls. The potential application of chicken feather waste for textile raw material insulators is still not widely studied. Chicken feathers have a lightweight, strong, porous and hydrophob, so it is potentially used as a textile insulation material. In this research, the chicken feather waste is sorted and cleaned by chemical process then processed into Nowoven fabric with polypropylene net with themal bonded method. The experiments were conducted by varying the comparison of the orientation of chicken feathers to produce the optimal insulation material which is evaluated from tensile strength and elongation, thermal properties of the material and area density. The result of density area testing (gramation) is known that the gramation of nowoven fabric insulator made from chicken feather waste 14 times heavier from material gramation of commercial insulator. The result of tensile test showed that nowoven fabric made from chicken feather waste with unidirectional orientation has 6 times higher tensile strength than tensile strength of commercial insulator material.
\end{abstract}

Keywords: chicken feathers, thermal bonded, nowoven, insulators 


\section{PENDAHULUAN}

Untuk mengatasi permasalah lingkungan dan menghasilkan produk dengan nilai tambah tinggi dari limbah bulu ayam ini maka diperlukan suatu penelitian yang memadai. Diketahui dari penelitian sebelumnya bahwa secara kimia bulu ayam terdiri dari $91 \%$ keratin, $1.3 \%$ lemak dan $7.9 \%$ air. Keratin adalah suatu senyawa protein sehingga dapat digunakan sebagai pakan ternak, namun proses ini memerlukan pemanasan tinggi, biaya energi mahal dan rusaknya kandungan asam amino sehingga kualitas gizi dan harga jualnya rendah. Salah satu potensi yang cukup menjanjikan dari limbah bulu ayam ini adalah dengan memanfaatkan sifat fisik dari bulu ayam yang ringan, kuat, berpori, dan sedikit hidrofob, daya lenting baik, penahan panas yang baik dimana sifat ini diperlukan untuk tekstil insulator. Bahan tekstil insulator dari bulu ayam ini diyakini memiliki keunggulan diantaranya dapat terurai oleh alam karena tersusun dari senyawa protein sehingga lebih ramah lingkungan dibanding material insulator yang terbuat dari polimer sintetik seperti poliester dan serat gelas, biaya produksi lebih rendah karena memanfaatkan limbah sekaligus mengurangi pencemaran lingkungan. Pada percobaan ini bulu ayam yang telah disortir dan dibersihkan dibuat menjadi kain Nowoven dengan metoda thermal bonded menggunakan mesin skala laboratorium yang dirancang tersendiri. Beberapa penelitian sebelumnya yang memanfaatkan limbah bulu ayam lebih banyak membahas tentang penggunaanya sebagai bahan baku pakan ternak. Penelitian lain menggunakan limbah bulu ayam untuk dijadikan material penyaring udara melalui proses Nowoven metode neddle punching dan pembuatan serat regenerasi keratin dengan melarutkan bulu ayam pada pelarut ionic seperti yang dapat dilihat pada Gambar.1.

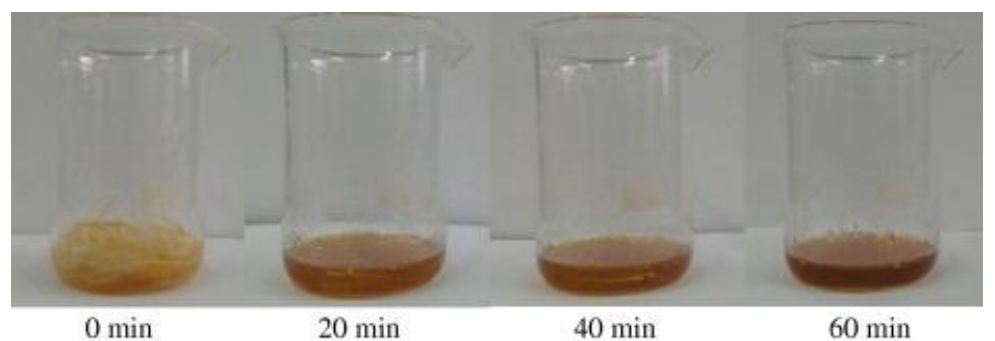

Gambar 1. Pelarutan Bulu Ayam Menggunakan Pelarut lonik Sumber: Separation and Purification Technology, Volume 132, 2014

\section{METODA PENELITIAN}

Penelitian ini dirancang agar sedapat mungkin menggunakan material dan peralatan yang mudah diperoleh di pasaran, hal ini ditujukan agar hasil penelitian dapat diaplikasikan oleh Industri Kecil Menengah. Penelitian dilakukan di Laboratorium Penelitian Politeknik STTT Bandung dan lembaga pengujian terkait.

\subsection{Alat dan Bahan}

\subsubsection{Alat}

Penelitian ini dilakukan dengan Mesin thermal bonding dengan metode batch system, lemari pendingin, oven, pemanas, sensor panas digital dengan thermocouple, dan thermometer gun.

\subsubsection{Bahan}

Limbah bulu ayam negeri, jaring polypropilen (sun screen), scouring agent, alkohol, PE foam, bubble warp, alumunium foil. 


\subsection{Metode}

\subsubsection{Proses Pembuatan Nowoven Insulator}

Bulu ayam disusun sesuai dengan orientasi di atas permukaan alumunium foil. Di bagian tengah dari lapisan bulu ayam terdapat lapisan jaring polipropilen yang berfungsi sebagai binder agar bulu ayam melekat satu dengan yang lainnya. Setelah lapisan bulu ayam paling atas kemudian diletakan kembali alumunium foil yang berfungsi melindungi material pada saat proses pemanasan berlangsung.

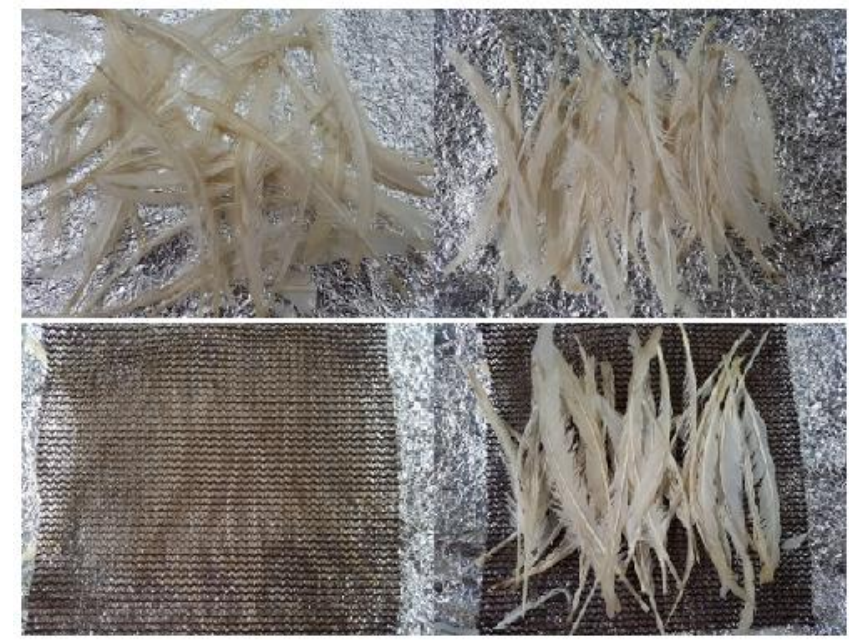

Gambar 2. Skema Proses Manufaktur Hand lay-up

Parameter proses yang digunakan pada saat pembuatan kain nowoven ini adalah sebagai berikut:

- Berat bulu ayam : 10 gram

- Berat jaring polipropilen : 4,5 gram

- Ukuran jaring polipropilen : 20x $0 \mathrm{~cm}$

- Temperatur pemanasan : $125^{\circ} \mathrm{C}$

- Tekanan pemanas : : $10 \mathrm{psi}$

- Waktu pemanasan : $: 2 \times 3$ menit

- Arah orientasi bulu ayam : acak, silang \& unidirectional (searah)

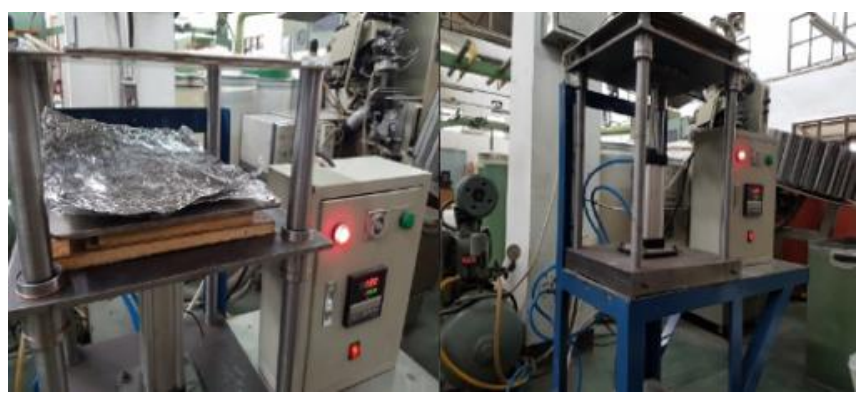

Gambar 3. Proses Thermal Bonding

\subsubsection{Pengujian Area Density}

Pada penelitian ini akan diamati sifat fisik kain nonwoven yang dihasilkan dengan fokus areal density. Areal density akan dipengaruhi oleh fraksi berat dan fraksi volume dari material bulu ayam dan serat limbah plastik polipropilenyang berfungsi sebagai perekat. Nilai areal density dinyatakan dalam satuan gram/m2. Pengukuran nilai areal density dilakukan dengan cara ditimbang dengan menggunakan timbangan gramasi dan kemudian dilakukan perhitungan dengan rumus perbandingan. 


$$
M=\frac{m}{a}
$$

Keterangan:

$$
\begin{aligned}
& \mathrm{M}=\text { areal density }\left(\mathrm{gram} / \mathrm{m}^{2}\right) \\
& \mathrm{m}=\text { berat kain nonwoven }(\mathrm{g}) \\
& \mathrm{a}=\text { luas permukaan kain }\left(\mathrm{m}^{2}\right)
\end{aligned}
$$

Semakin rapat jarak antar serat pada kain nonwoven akan menyebabkan nilai areal density yang lebih tinggi dan begitupun berlaku sebaliknya. Nilai areal density yang lebih tinggi akan menyebabkan jarak antar serat yang lebih rapat. Jarak antar serat dapat berpengaruh terhadap peningkatan sifat mekanik terutama peningkatan kekuatan tarik. Semakin rapat jarak rapat pada kain nonwoven maka nilai kekuatan tarik kain tersebut akan semakin tinggi. Hal tersebut disebabkan friksi dan ikatan antar serat yang lebih tinggi sehingga kain akan lebih sulit untuk berdeformasi.

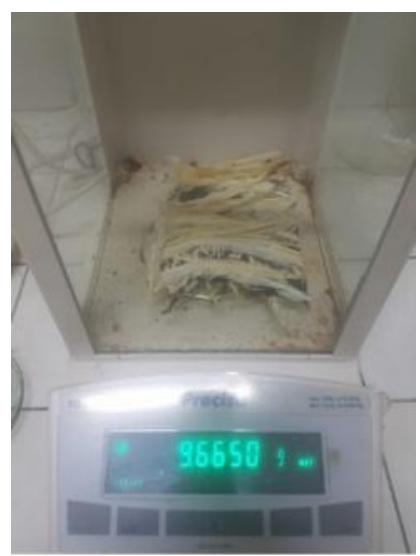

Gambar 4. Penimbangan Material untuk Perhitungan Area Density

\subsubsection{Uji Kekuatan Tarik}

Sifat mekanik yang akan diamati pada penelitian ini adalah kekuatan tarik dan elongation melalui pengujian tarik. Pengujian tarik bertujuan untuk mengetahui kekuatan tarik dengan cara memberikan beban tarik secara bertahap pada contoh uji hingga contoh uji tersebut mengalami putus. Pengujian kekuatan tarik kain nonwoven dilakukan dengan menggunakan acuan SNI 084417-97 dengan menggunakan instrumen uji tarik. Prinsip kerja instrumen uji tarik ini adalah memberikan beban tarik dengan kecepatan tertentu. Pada saat proses pengujian, penambahan panjang yang dialami oleh contoh uji akan direkam beserta beban maksimal hingga contoh uji tersebut putus. Instrumen pengujian tarik dapat dilihat pada Gambar 4. Hasil pengujian tarik dapat berupa grafik dengan sumbu- $X$ menunjukan pertambahan panjang contoh uji dan sumbu-Y menunjukan beban yang diberikan. 


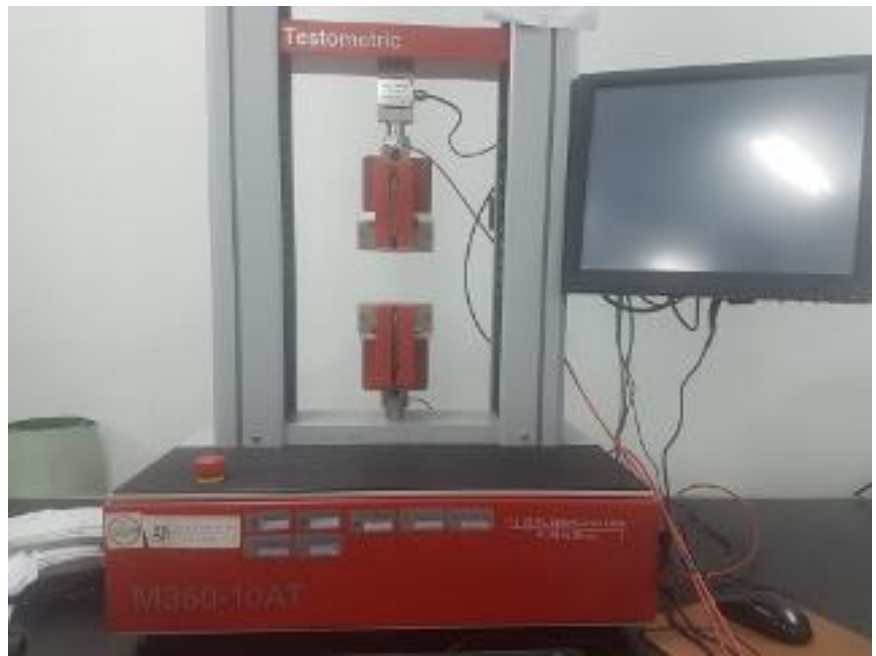

Gambar 4. Alat Uji Tarik Tetsometric

\section{HASIL DAN PEMBAHASAN}

\subsection{Nonwoen Insulator B erbahan Limbah Bulu Ayam}

Kain nowoven yang dihasilkan dari proses produksi menggunakan mesin thermal bonding yang dirancang dalam penelitian ini memiliki struktur yang baik. Hal ini dapat dilihat dari daya rekat jaring polipropilen yang optimal sehingga antara bulu ayam yang satu dengan lainnya menempel dengan baik. Hasil ini menandakan bahwa parameter proses yang didapatkan dari percobaan awal sudah optimal. Temperatur proses diatur dalam kisaran 120-130 ${ }^{\circ} \mathrm{C}$, sedikit lebih rendah dari yang disebutkan pada literatur yaitu $130{ }^{\circ} \mathrm{C}$ (Maier.C, 1998) dikarenakan pada proses ini diharapkan jaring polipropilen tidak meleleh secara keseluruhan/sebagian. Jaring polipropilen yang meleleh sebagian ini yang menghasilkan stabilitas kain Nowoven yang dihasilkan dikarenakan jaring polipropilen masih memiliki ikatan-ikatan dengan bentuk yang masih teratur mendekati bentuk awalnya (bujursangkar).

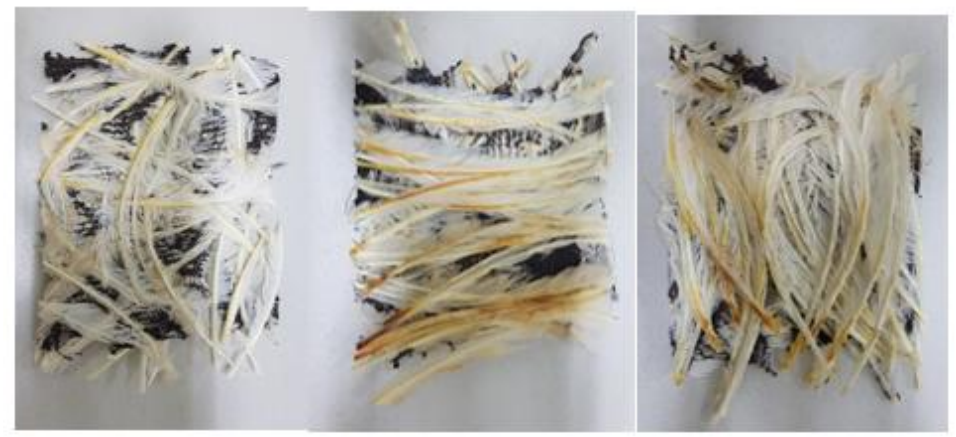

Gambar 5. Nonwoven Berbahan Utama Limbah Bulu Ayam

Pada kain nowoven dengan orientasi acak, beberapa bagian secara visual nampak lebih tebal dibandingkan dengan bagian lainnya. Pada bagian yang lebih tebal tersebut, bulu ayam pada lapisan terluar tidak terjangkau oleh lelehan jaring polipropilen. Hal tersebut menyebabkan bulu ayam rentan terlepas dari kain nowoven. Pada kain nowoven dengan orientasi unidirectional dan silang, lelehan jaring polipropilen dapat mencapai hampir keseluruhan lapisan bulu ayam sehingga bulu ayam dapat terikat dengan baik. Secara visual kain nowoven dengan orientasi unidirectional dan silang nampak lebih rata dibandingkan dengan kain nowoven dengan orientasi acak. Bentuk struktur pada kain nowoven akan mempengaruhi sifat mekanik dan sifat termal dari kain nowoven tersebut. 


\subsection{Pengujian area density (gramasi) kain Nowoven}

Berdasarkan hasil pengujian area density (gramasi) diketahui bahwa gramasi kain Nowoven insulator yang berbahan utama limbah bulu ayam memiliki nilai lebih dari 14 kali lipat dari gramasi material insulator komersial. Gramasi insulator berbahan limbah bulu ayam mencapai hingga 575 $\mathrm{gram} / \mathrm{m} 2$ sedangkan gramasi material insulator komersial terhitung hanya $40 \mathrm{gram} / \mathrm{m} 2$. Hal ini disebabkan material insulator komersial memiliki ruang-ruang yang ditempati udara.

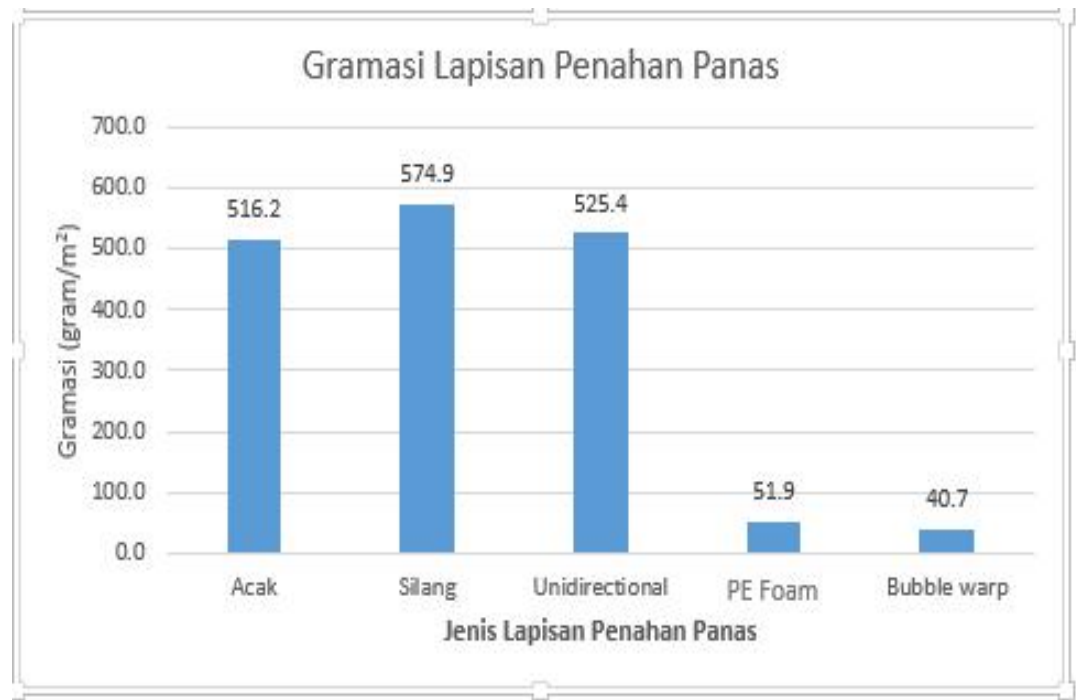

Gambar 6. Gramasi Nonwoven Berbahan Utama Limbah Bulu Ayam

Gramasi material insulator panas sangat penting untuk aplikasi penahan panas atap bangunan, semakin tinggi gramasi maka beban yang harus ditanggung oleh bangunan akan semakin besar. Dengan demikian, gramasi material insulator panas harus dibuat seminimal mungkin terutama untuk mencegah hal buruk yang dapat berdampak pada keselamatan pada penggunaanya. Pemilihan material jaring polipropilen sudah sangat tepat dikarenakan material ini memiliki massa jenis yang relatif rendah, yaitu : $0,9 \mathrm{gram} / \mathrm{cm}^{3}$. Massa jenis dari polipropilen ini berada di bawah material plastik yang umum digunakan seperti polyester yang memiliki massa jenis $1,37 \mathrm{gram} / \mathrm{cm}^{3}$ ataupun nylon yang memiliki massa jenis sebesar $1,15 \mathrm{gram} / \mathrm{cm}^{3}$.

\subsection{Uji Kekuatan Tarik dan Mulur}

Hasil pengujian uji tarik menunjukan kain nowoven berbahan utama limbah bulu ayam dengan arah orientasi unidirectional memiliki kekuatan tarik 6 kali lebih tinggi dibandingkan dengan kekuatan tarik material insulator komersial. Kekuatan tarik kain nowoven berbahan utama limbah bulu ayam dengan arah orientasi unidirectional mencapai 15,4 kgf apabila dilakukan searah dengan arah orientasinya namun kondisi tersebut jauh berbeda apabila arah penarikan diubah menjadi tegak lurus dengan arah orientasinya, yaitu 1,3 kgf. Kondisi paling ideal dimiliki oleh kain nowoven berbahan utama bulu ayam dengan orientasi silang dengan kekuatan tarik yang serupa pada 2 sumbunya yaitu $7,8 \mathrm{kgf}$. Kekuatan tarik kain nowoven berbahan utama limbah bulu ayam dengan arah orientasi acak hanya mencapai 2,8 kgf, nilai tersebut lebih rendah dibandingkan dengan kekuatan tarik material insulator komersial berbahan bubble warp. 


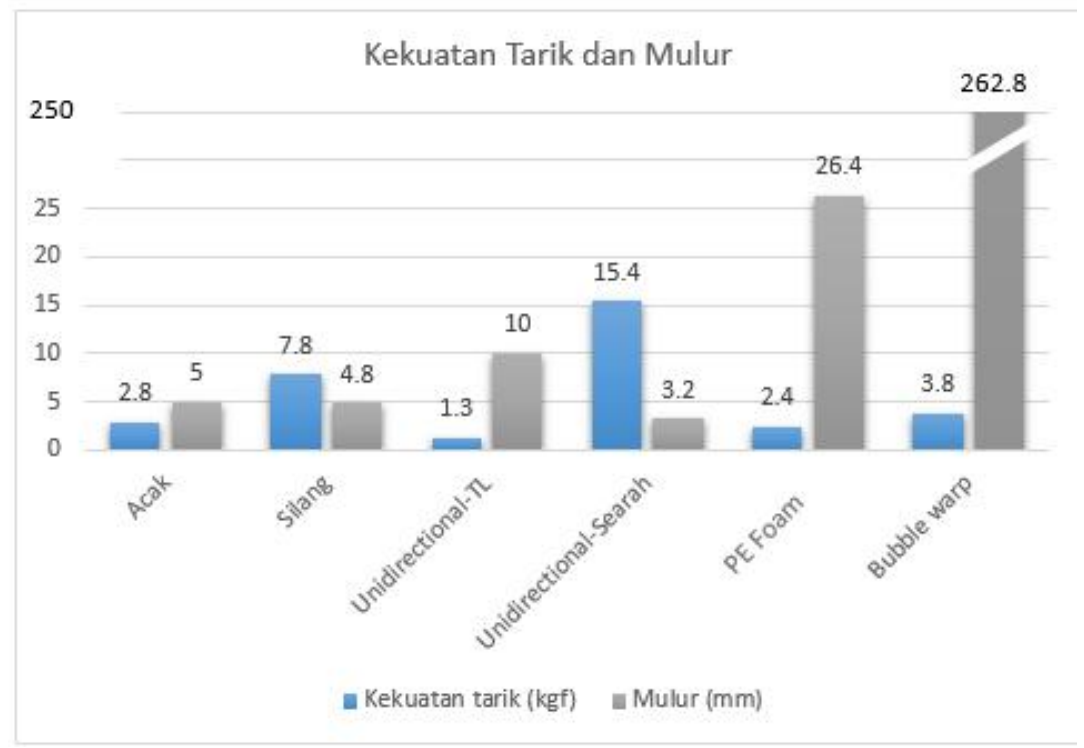

Gambar 6. Kekuatan Tarik dan Mulur Nonwoven Berbahan Utama Limbah Bulu Ayam

Kekuatan tarik sebuah material akan berbanding terbalik dengan mulur material tersebut, material insulator komersial. Pada kain nonwoven berbahan utama limbah bulu ayam, nilai mulur tertinggi dicapai oleh orientasi unidirectional ke arah tegak lurus dengan nilai $10 \mathrm{~mm}$. Kondisi paling ideal dimiliki oleh kain nonwoven berbahan utama bulu ayam dengan orientasi silang dengan nilai mulur yang serupa pada 2 sumbunya yaitu $4,8 \mathrm{~mm}$. Kekuatan tarik dan mulur sangat penting untuk proses penangangan material tersebut baik ketika proses produksi berlangsung ataupun pada saat penggunaannya. Material insulator panas dengan kekuatan tarik rendah akan menyebabkan material mudah sobek ketika proses penggulungan pada tahap akhir produksi dan pemasangan atau perekatan pada alumunium foil.

\section{KESIMPULAN}

Berdasarkan eksperimen yang dilakukan diketahui bahwa

a. Kain nowoven sebagai insulator berbahan utama bulu ayam berhasil dibuat dengan menggunakan mesin thermal bonding pada temperatur proses $125^{\circ} \mathrm{C}\left(+/-5^{\circ} \mathrm{C}\right)$, tekanan pemanas 10 psi dan waktu pemanasan 6 menit.

c. Hasil pengujian area density (gramasi) diketahui bahwa gramasi kain nowoven insulator yang berbahan utama limbah bulu ayam memiliki nilai lebih dari 14 kali lipat dari gramasi material insulator komersial.

d. Hasil pengujian uji tarik menunjukan kain nowoven berbahan utama limbah bulu ayam dengan arah orientasi unidirectional memiliki kekuatan tarik 6 kali lebih tinggi dibandingkan dengan kekuatan tarik material insulator komersial. 


\section{DAFTAR PUSTAKA}

1. Betty F. Smith \& Ira Block, Textiles in Perspective, Prentice-Hall,Inc. \& A. B. Thompson Fiber structure Edited by J. W. Hearle and R. H. Peters, Butterworth \& Co. Ltd. and the Textile Institute

2. B. Aldousiri, M. Alajmi,2 and A. Shalwan, Mechanical Properties of Palm Fibre Reinforced Recycled HDPE, Advances in Materials Science and Engineering ; 2013.

3. Barone, J.R. and Schmidt, W.F.; Polyethylene Reinforced with Keratin Fibers Obtained from Chicken Feathers, Composites Science and Technology (2005).

4. Callister, W.D, Jr. "Material Science and Engineering An Introduction", 6th Edition, John Willey \& Sons, New York. 2003.

5. Ganesh Tapkire, Satish parihar, Pramod Patil, Hemraj R Kumavat, Recycled Plastic Used In Concrete Paver Block, International Journal of Research in Engineering and Technology vol $3,2014$.

6. Fraser, RDB; MacRae, TP; Rogers, GE.; Keratins: their composition, structure, and Biosynthesis; Springfield: Charles C. Thomas Publisher; 1972.

7. Gerald Scott, (1999): Polymers and The Environment, The Royal Society of Chemistry, Cambridgde. UK.

8. J. Krager-Kocsis, 1999: Polypropylene: An A-Z reference, Kluwer Accademic Publisher, London. Great Britain.

9. Kandasamy, R. and Murugesan, R. 2011. Fibre reinforced concrete using domestic waste plastics as fibres. Ournal of. Enggineering Application Science; 2011

10. Kubo, S.; Gilbert, R.D.; Kadla, J.F. Lignin-based polymer blends and biocomposite materials. Natural Fibers, Biopolymers, and Biocomposites. 2005, 671-697.

11. Malcolm P. Steven, 1989: Polymer Chemistry: An Introduction,Oxford University Press, Inc.

12. Maier C., Calafut T.,Polypropylene: The Definitive User's Guide and Databook, William Andrew Publishing/Plastics Design Library, 1998, ISBN 978-1-884207-58-7.

13. Martinez-Hernandez, Ana L.; Velasco-Santos, Carlos; De Icaza, Miguel;Castano, Victor M.; Microstructural characterisation of keratin fibres from chicken feathers; International Journal of Environment and Pollution; 23(2), 2005.

14. Narendra Redy et.al, Structure and Properties of Chicken Feather Barbs as Natural Protein Fibers, Journal of Polymers and the Environment 15, 2007.

15. Rock, J. W.; Barbieri, R. J.; Justice, J. M.; Kurtis, K. E.; Gentry, T. R.; Nanko, H.; Characterization of chicken feather materials for use in biocomposites; Proceedings of the American Society for Composites, Technical Conference ,2005.

16. Schmidt, WF; Line, MJ; Physical and chemical structures of poultry feather fiber fractions in fiber process development. In: TAPPI Proceedings: 1996.

17. V.Vytlacilov "The fibre reinforced concrete with using recycled aggregates" International Journal of Systems Applications, Engineering \& Development Issue 3, Volume 5, 2011.

18. Woodin, A. M.; Molecular size, shape and aggregation of soluble feather keratin.Biochem. J. 57, 1954. 